\title{
Diabetic Control on Once- and Twice-daily Insulin Injections
}

Dear Sir,

In the June 1980 edition of Diabetologia, Tchobroutsky et al. [1] reported a significant inverse correlation between the number of daily insulin injections and the $\mathrm{HbA}_{1 \mathrm{c}}$ concentrations. In a recent study we have failed to find such a relationship.

We measured $\mathrm{HbA}_{1(\mathrm{a}+\mathrm{b}+\mathrm{c})}$ concentrations in a sample of 376 diabetic out-patients, established on once or twice-daily insulin injections, at one of two teaching hospitals (Table 1). No patient whose regimen had been changed within six months was included in the study. $\mathrm{HbA}_{1}$ was estimated by a rapid column chromatographic method [2]. The within and between assay variability were $<3 \%$ and $<4 \%$ respectively. The distributions of the $\mathrm{HbA}_{1}$ levels in the once and the twice-daily injection groups and comparisons between the means were analysed for each hospital separately and for both together using the Kolmogorov-Smirnoff and Student $t$ test methods respectively, after the data had been shown to be normally distributed.

No significant differences were found between patients on once and on twice-daily injections either by comparing the means of $\mathrm{HbA}_{1}$ levels or by comparing their distribution (Table 1 ). This applied whether data from the two hospitals was analysed separately or collectively. The numbers studied were sufficient to exclude the possibility of a type II error in analysis for differences at the $5 \%$ level or above [3]. Only $18.1 \%$ of the once-daily and $21.0 \%$ of the twice-daily group had $\mathrm{HbA}_{1}$ levels within our normal range (i. e. below an $\mathrm{HbA}_{1}$ of $10.5 \%$ or within 1.7 standard deviations of our non-diabetic patient mean). Tchobroutsky et al. give figures (based upon $\mathrm{HbA}_{1 \mathrm{c}}$ values falling within three standard deviations of the normal mean) of $4 \%$ for those on once-daily injections, $21 \%$ for those on twice-daily injections and $19 \%$ for all groups combined. The discrepancy is thus most obvious between the results obtained in the once-daily injection groups and would be accentuated if a range within 2 standard deviations of the normal mean were used in Tchobroutsky's analysis. This could either reflect an unrepresentative sample of 25 patients on once-daily insulin in Tchobroutsky et al's data or suggest that $\mathrm{HbA}_{1 \mathrm{c}}$ is a better discriminant of poor control than $\mathrm{HbA}_{1(\mathrm{a}+\mathrm{b}+\mathrm{c})}$.

While our results are disappointing in failing to support those of Tchobroutsky et al. it is clear that most of our patients on divided doses of insulin had been started on them because of difficulties in management with once-daily insulin. On clinical grounds, therefore, this group might have been expected to be less well controlled than those on once-daily insulin.

The difference in ages, as Tchobroutsky et al. suggest, may explain the differences they found between the groups. $\mathrm{HbA}_{1}$ also rises with age and since our twice-daily dose patients were younger than those on single doses they could have been expected to have lower $\mathrm{HbA}_{1}$ levels, but comparable levels of control may still have been achieved because of the use of divided doses for the more difficult patients. Comparison of regressions of $\mathrm{HbA}_{1}$ on age in Tchobroutsky's data may clarify this point.

Prospective studies of long-term control will be needed to define the contributions of divided insulin doses to patientcare as compared to the many other factors affecting control.

B. J. Boucher, C. Walton, S. G. Welch, D. Barnett, J. S. Yudkin, and J.P. Monson

\section{References}

1. Tchobroutsky G, Charitonsky D, Blonquit Y, Papoz L, Sonia J, Rosa J (1980) Diabetic control in 102 insulin treated out-patients. Diabetologia 18: 447-452

2. Welch SG, Boucher BJ (1978) A rapid micro-scale method for the measurement of haemoglobin $A_{1(a+b+c)}$. Diabetologia 14: 209-211

3. Freiman JA, Chalmers TC, Smith H, Kuebler RR (1978) The importance of Beta, the type II error and sample assays in the design and interpretation of the randomized control trial. $\mathrm{N}$ Engl J Med 299: 690-694

Dr. B. J. Boucher

Metabolic and Endocrine Unit

The London Hospital

London E1 1BB

England

Table 1. Values of Glycosylated haemoglobin $\left(\mathrm{HbA}_{1}\right)$ in patients from two hospitals; on once or on twice daily insulin. Comparison of group means ( $\mathrm{t}$ test) and distribution $(\mathrm{z})($ see text)

\begin{tabular}{|c|c|c|c|c|c|c|c|c|}
\hline Patient & Groups & $\mathrm{n}$ & $\begin{array}{l}\text { Mean } \\
\text { HbA, \% }\end{array}$ & \pm & $\begin{array}{l}\text { Standard } \\
\text { error }\end{array}$ & $\begin{array}{l}\text { Significance } \\
\text { of } t \text { test }\end{array}$ & $\begin{array}{l}\% \text { in normal range } \\
\left(\mathrm{HbA}_{1}<10.5 \%\right)\end{array}$ & $\begin{array}{l}\text { Significance } \\
\text { of } z \text { test }\end{array}$ \\
\hline L. H. ${ }^{\mathrm{a}}$ & Total & 188 & 12.87 & \pm & 0.19 & NS & 19.1 & NS \\
\hline S. J. H. ${ }^{b}$ & Total & 188 & 12.66 & & 0.18 & & 19.6 & \\
\hline L. $\mathrm{H}^{\mathrm{a}}$ & Once daily & 109 & 12.84 & \pm & 0.24 & NS & 18.3 & NS \\
\hline L. $H^{a}{ }^{a}$ & Twice daily & 79 & 12.92 & \pm & 0.30 & & 20.2 & \\
\hline S. J. H. ${ }^{b}$ & Once daily & 115 & 12.66 & \pm & 0.21 & NS & 18.3 & NS \\
\hline S. J. H. ${ }^{b}$ & Twice daily & 73 & 12.65 & \pm & 0.31 & & 21.9 & \\
\hline L. $H^{a}+$ S. J. H. ${ }^{b}$ & Once daily & 224 & 12.75 & \pm & 0.16 & NS & 18.1 & NS \\
\hline L. ${ }^{a}{ }^{a}+$ S. J.H. ${ }^{b}$ & Twice daily & 152 & 12.79 & \pm & 0.22 & & 21.0 & \\
\hline
\end{tabular}

\footnotetext{
${ }^{\text {a }}$ London Hospital

b St. James Hospital, Leeds
} 